\author{
Birutė Obelenienè*, Gintarè Gabševičienè* \\ Vytautas Magnus University, Kaunas, Lithuania
}

\title{
Causes of Conflict in Marriage as Expressed by Moderators and Participants of the “Encounters of Married Couples" Programme
}

\section{Introduction}

The unity of the spouses faces challenges at all times. "Their union has always been threatened by discord, a spirit of domination, infidelity, jealousy, and conflicts that can escalate into hatred and separation"1. Conflict in every situation can become either a creative or a destructive power. Conflict is inevitable in every family's life. If there are no conflicts in the family, it does not mean that this family is harmonious; spouses might be distant, estranged or indifferent to each other and therefore there are no disagreements in their relationship.

Harmonious spousal relationship is very much linked to their ability of solving conflicts. In order to solve conflicts effectively, it is important to understand the situation that provoked the conflict, to ascertain the causes of conflict, to know

* BIRUTÉ OBELENIENĖ is a Doctor of Social Sciences (Science of Education), Professor in the Theology Department, Senior Researcher of Research Center on Marriage and Family of Catholic Theology within the Faculty in Vytautas Magnus University (Lithuania). The main research interests are sexual ethics, bioethics and youth preparation for family life.

* GINTARÉ GABŠEVIČIENĖ holds a Masters Degree of Education Science from the Vytautas Magnus University (Lithuania) with a particular interest in research about the family. Research interests include spousal conflicts resolution and harmony of spousal relationship.

1 CCC 1606. 
oneself and one's partner well, to have knowledge and skills that would help solving conflicts constructively.

Studies in Lithuania show that spouses in Lithuanian families often dispute over the consumption of alcohol (42 percent), the division of housework (41 percent), relationships with friends and relatives ( 35 percent). Women usually dispute over family's inner life issues (roles, power, consumption of alcohol), while men dispute over family's external relationships (leisure, relationships with friends and relatives) ${ }^{2}$. Conflicts often arise when one person's behavior, while performing a certain role in the family, is not compatible with the expectations of another person performing another role. It was noted that multiple roles in the family contributed to family conflicts. Most employees experience stress related to the workload, difficulties and time constraints, which can lead to a family conflict ${ }^{3}$. On investigation, A. M. Sultana concludes that it is necessary to oblige to pre-defined rules and discipline in marriage, because it helps dealing with work and family responsibilities. His study reveals that satisfaction and stress at work directly affect person's behavior in the family and are related to the frequency of conflicts ${ }^{4}$.

This article analyses causes of conflict as expressed by moderators and participants of the "Encounters of Married Couples" programme ${ }^{5}$. It is a weekend programme for married couples designed to strengthen the relationship between spouses and foster mutual dialogue and understanding. This programme is coordinated by the Lithuanian Family Center and has been implemented in Lithuania since 1992. During this period of time over 200 married couples took part in these weekend programmes in various parts of Lithuania.

Object of the research - causes of conflicts experienced by participants of the "Encounters of Married Couples" programme.

2 A. Maslauskaitè, Tarpusavio santykių kokybe Lietuvos šeimose, "Sociologija. Mintis ir veiksmas" (2005) Nr. 1, p. 123-130.

3 A. M. Sultana, A Study on Stress and Work Family Conflict among Married Women in Their Families, "Advances in Natural and Applied Sciences" (2012), Vol. 6 (8), p. 1319-1324.

4 A. M. Sultana, A Study on Stress and Work Family Conflict among Married Women in Their Families, "Advances in Natural and Applied Sciences" (2012), Vol. 6 (8), p. 1319-1324.

5 On 15 August, 2014 The Pontifical Council for the Laity approved the statute of the "Encounters of Married Couples" (Spotkania Małżeńskie) and legalized this recollection movement as "International private association of the faithful of Pontifical Right". In Vatican it was officially approved by its English name "Encounter of Married Couples" with the right for each country to use appropriate name in local language. 
Goal - to reveal causes of conflict of married couples who participated in the "Encounters of Married Couples" programme.

Tasks:

1. To theoretically summarize the causes of a couple's conflict;

2. To assess the causes of conflict experienced by married couples who participated in the "Encounters of Married Cs" programme and to assess programme's influence on the change of causes of conflict.

Research methods: literature analysis, systemic and structural analysis, qualitative (focus group) and quantitative (comparative) research. Interviews and semi-structured surveys were used to gather data, which was analyzed by content analysis and quantitative data analysis methods.

\section{Causes of Marital Conflict}

Marital conflict has various causes. In order to better understand and learn how to control conflict, it is very important to analyze and understand what reasons lead to it. Conflicts often arise due to unmet needs or intersection of interests in a certain situation ${ }^{6}$. One of the main sources of conflict is poor communication with each other. Positive communication can be a solution of a conflict. Everything depends on methods of interacting with each other. When negative feelings are allowed to spread, there are always enough reasons to maintain a conflict ${ }^{7}$. One of the most common causes of conflict is that spouses are unable to look at the situation in a flexible way and without prejudice ${ }^{8}$.

K. Miškinis ${ }^{9}$ identifies the most important marital causes of conflict:

- Conflicts related to faith. Nowadays newlyweds create an ideal image of each other and get married without knowing each other well. After a few months of living together their expectations are not met; they see each other as they are and the conflict begins.

6 A. Maslauskaitè, Tarpusavio santykių kokybe Lietuvos šeimose, "Sociologija. Mintis ir veiksmas" (2005) Nr. 1, p. 123-130.

7 T.L. Zacchilli, C. Hendrick, S. S. Hendrick, The Romantic Partner Conflict Scale: A New Scale to Measure Relationship Conflict, "Journal of Social and Personal Relationships" (2009), Vol. 26 (8), p. 1073-1096.

8 J. Almonaitienė, Bendravimo psichologija, Kaunas: Technologija 2001.

9 K. Miškinis, Šeima žmogaus gyvenime, Kaunas: Aušra 2003, p. 392. 
- Conflicts for dominance. Spouses do not want to relent, give up their principles, listen to one another; this is how fights and quarrels over various details begin. When one of the spouse's interests and opinion are ignored in the marriage, a couple's conflicts begin.

- Conflicts over child bearing. Conflicts arise for this reason because spouses do not know how to plan the family consciously. Also, on the birth of a child, the burden of domestic issues increases, fatigue occurs and material situation worsens.

- Conflicts caused by poor communication. Spouses must communicate; otherwise they are unable to keep their spiritual balance. When difficulties arise, spouses' inhibitions are lowered: they start to shout, insult, and strong conflicts arise.

- Conflicts due to material-domestic difficulties. Usually couples get married not having any material sources. Material difficulties give rise to conflicts.

One very significant cause of conflic, which has a negative impact on the relationship between spouses, are excessive working hours and great stress at work. This is because this makes a spouse unable to spend some quality leisure time with his/her partner and willingness to meet his/her needs ${ }^{10}$. Also, one of the main causes of conflict is the dissimilarity of the needs of spouses. One spouse might need more space and need to be alone, while the other might need more attention and spending leisure time together with his/her spouse. Different needs in the marriage can be adjusted: firstly, mutual trust is very important; secondly, there must be commonly agreed rules, workload must be divided equally and done together. Many conflicts can be solved in a positive way, but for that to happen spouses must have positive communication with each other, a close relationship, empathy and mutual trust. Above all, there must be constant communication ${ }^{11}$.

Most commonly, conflicts between spouses arise due to money, sex, relatives, religion and education of children. In fact, conflict situations in families arise due to various reasons, because families are faced with the relationships between two or more people, and each of them is an individual. Therefore, it is very important for spouses to learn to respect each other's individuality ${ }^{12}$.

10 K. L. Minnotte \& C. M. Minnotte \& D. E. Pedersen \& S. E. Mannon \& G. Kiger, Hisand Her Perspectives: Gender Ideology, Work-to-Family Conflict, and Marital Satisfaction, "Sex roles” (2010), Vol. 63, p. 425-438.

11 J. Orathinkal, A. Vansteenwegen, Couples' conflicts: A territorial perspective, "Sexual and Relationship Therapy" (2006), Vol. 1, p. 28-44.

12 G. Matulienè, Šeimos psichologija, Vilnius: Ciklonas 2012, p. 89. 
G. Matulienè defined these sources of conflicts:

- Differences in perception. Spouses' different approaches to the same subject. In marriage, it is important to find out how each spouse perceives various subjects and their meaning.

- Different values. Often quarrels are caused by differing spouses' attitudes to material and spiritual values. Conflicts in the family are also increased by differing spouses' attitudes towards lifestyle, responsibility and religion.

- Dominance in interpersonal relations. Rivalry occurs in relationships when spouses make decisions independently without discussing them with each other. When interpersonal relations are more flexible and agreements are clearer, there is less chance of conflicts between spouses.

- Stress at work. If spouses are satisfied with their jobs, they are more satisfied with their marital life. Failures at work cause stress and frustration which are then brought back home and displaced on other family members.

- Violation of unwritten rules. It often happens that spouses understand certain rules of behavior differently. If these rules are violated, conflicts arise.

- Behavior. Conflict can arise when one spouse acts in the way which the other would not want. Spouses should discuss conflict causes and commit not to hurt each other.

- Poor communication habits. Conflict also arises due to main habits of incorrect communication: domination of one's truth, sense of victimization, denial, perfectionism, distraction, lack of the need to listen. Recognition of such poor communication habits is certainly a step in self-change which may affect interpersonal relations ${ }^{13}$.

\section{Methods of the research of causes of conflict as expressed by moderators and participants of the "Encounters of Married Couples" programme}

In order to reveal and further analyze causes of conflict of spouses who participate in the "Encounters of Married Couples" programme, two research methods were employed: a) qualitative, focus group method, which was applied for moderators of the programme; b) quantitative (semi-structured survey) method, which was applied for the participants of the programme. Both these research methods

13 G. Matulienè, Šeimos psichologija, Vilnius: Ciklonas 2012, p. 89. 
complement each other, contribute to better insight into the research and assist in reaching its goal.

Focus groups were the method used to qualitatively research the experience of moderators of the "Encounters of Married Couples" programme. This method was useful to gather information for the construction of the quantitative research survey tool, as well as to supplement and compare the results. Focus groups were also used to find out the causes of conflict experienced by the moderators while participating in the programme. During the discussion of the focus group the following questions were asked: 1) what reasons caused conflicts in your family before participation in the "Encounters of Married Couples" programme?; 2) what causes conflicts between you now?; 3) what changed in your interpersonal relations after you began participating in the "Encounters of Married Couples" programme?

A quantitative survey was used to gather the experience of the participants of the "Encounters of Married Couples" programme. Participants were surveyed in three stages. The first survey was carried out before the "Encounters of Married Couples" programme. It was comprised of 9 questions, 3 of them were openended. Demographic data was collected by questions about age, sex, duration of marriage, church marriage, and number of children. The questionnaire asked about expectations for the "Encounters of Married Couples" programme, the satisfaction of one's marriage, the causes of conflict. The questionnaire was constructed based on the data of focus group research. The second stage was carried out immediately after the programme. This questionnaire was comprised of four questions, all of which were open-ended. The questionnaire asked what participants liked most in the programme, whether their expectations were met, what aspects of relationship with their spouse they would like to change and what method is the best to solve conflicts. The third stage was carried out 3 months after the programme. This questionnaire was identical to the one used in the first stage.

\section{The selection of research participants}

Research participants were selected using criteria-based and convenience selections. Criteria-based selection allows collecting high-quality data and complying with set criteria while selecting appropriate and necessary people for the research ${ }^{14}$. Research participants had to meet certain criteria: 1) couples had to be married;

14 B. Bitinas, L. Rupšienè, V. Žydžiūnaite, Kokybinių tyrimu metodologija, Klaipèda 2008. S. Jokužio leidykla-spaustuvè. 
2) spouses had to participate or must have participated in the "Encounters of Married Couples" programme. This article seeks to reveal the change of causes of conflict experienced by spouses who participated in the programme. Therefore, married participants were needed for the research. Research participants had to have participated in the programme once or regularly.

Seven married couples participated in a focus group study. These couples were members of the "Encounters of Married Couples" community or moderators of the programme. The focus group discussion lasted for 1 hour and 40 minutes. Six married couples, who participated in the "Encounters of Married Couples" programme for the first time, took part in the survey. Spouses were asked to fill in the questionnaires before and after the programme. They were also asked to leave contact information so that they could be surveyed 3 months after the programme. Comparison of data allowed to measure potential impact of the programme on marital conflict causes.

\section{Research progress}

The research was carried out in May and October 2013. The focus group study of the moderators of "Encounters of Married Couples" programme was conducted at the Lithuanian Family Center in Kaunas. The survey of the participants of the programme took part in Guronys during the programme. The third survey after the programme was carried out via e-mail. The Director of the Lithuanian Family Center, who is also a coordinator of the programme, authorized the research on the "Encounter of Married Couples" programme and its participants. Later, spouses were asked to consent to participate in the research. With the permission of moderators of the programme the discussion of the focus group was recorded. Spouses, who participated in the programme for the first time, were asked to fill in questionnaires. The spouses filled them in before the programme and immediately after it. Three months after the programme, they sent in filled questionnaires by e-mail. Questionnaires were filled separately by wives and husbands.

\section{Processing of research data}

Data collected from the focus group were analyzed using content analysis, i.e. the frequency of the occurrence of all categories was counted. Collected data were categorized under titles and every category was divided in certain subcategories ${ }^{15}$.

15 K. Kardelis, Moksliniu tyrimu metodologija ir metodai, Vadovèlis, Šiauliai: Lucilijus 2007. 
Subcategories were based on the answers of respondents (citations from the interview). The definition of categories and subcategories is a process of interpretive nature, which aims to discover the meaning contained in the data.

Quantitative data analysis was performed by SPSS (Statistical Package for Social Science), version 17.0. SPSS allowed calculating means and standard variations of solutions of marital conflicts. Tables were drawn using Microsoft Office Excel 2007. In order to find out what statistical criteria were appropriate for statistical analysis, the normality of distributions was examined using Shapiro-Wilk test. During the analysis of the results, hypotheses were tested by Wilcoxon test, i.e. the non-parametric equivalent of the paired samples. Significance level was chosen as $\alpha=0,05$. Statistical analysis of data revealed that the survey was a reliable enough method. Internal reliability of the questionnaire was equal to Cronbach's alpha $=0,782$.

\section{Research ethics}

The studies were conducted following these ethical principles: research participants were granted confidentiality and anonymity; they were assured that no personal information would be revealed. Studies were based on voluntary participation. Every participant was asked if s/he agreed to participate in the research and each participant had the right to accept or refuse participation. Also, spouses were asked for permission to record the interview. Every participant was informed about the research topic and questions and was assured that collected data would only be used for research purposes. Each participant was informed about how long would the interview be and how much time would the filling of questionnaires take. Principles of privacy, respect and dignity of each research participant were also guarded. While conducting studies, efforts were made to avoid bias and prejudice as much as possible. No facts about the research were disguised; there were no conscious emphasis on certain subjects not any attempt to conceal other subjects, whichcould have influenced participants in one way or another. 


\section{Results of the research of the participants of the "Encounters of Married Couples" programme}

\subsection{Causes of conflict expressed by moderators of the "Encounters of Married Couples" programme}

As mentioned above, 7 married couples, who moderate encounters and have differing experience of married life and participation in the programme, took part in the research (see Table 1).

Table 1. Data about the moderators of the "Encounters of Married Couples" programme

\begin{tabular}{|l|l|l|}
\hline Spouses & Duration of marriage & Participation in the programme \\
\hline I couple & 15 years & 10 years \\
\hline II couple & 18 years & 3 years \\
\hline III couple & 31 years & 2 years \\
\hline IV couple & 6 years & 5 years \\
\hline V couple & 25 years & 3 years \\
\hline VI couple & 22 years & 12 years \\
\hline VII couple & 30 years & 15 years \\
\hline
\end{tabular}

The causes of marital conflict before participation in the "Encounters of Married Couples" programme are displayed below: (see Table 2).

Table 2. Causes of conflict experienced by the moderators of the "Encounters of Married Couples" programme before participating in it

\begin{tabular}{|c|c|c|c|c|c|c|c|c|}
\hline Significance & Conflict causes & $\begin{array}{c}\text { I } \\
\text { couple }\end{array}$ & $\begin{array}{c}\text { II } \\
\text { couple }\end{array}$ & $\begin{array}{c}\text { III } \\
\text { couple }\end{array}$ & $\begin{array}{c}\text { IV } \\
\text { couple }\end{array}$ & $\begin{array}{c}\mathrm{V} \\
\text { couple }\end{array}$ & $\begin{array}{c}\text { VI } \\
\text { couple }\end{array}$ & $\begin{array}{l}\text { VII } \\
\text { couple }\end{array}$ \\
\hline \multirow{3}{*}{$\begin{array}{l}\text { Very } \\
\text { significant }\end{array}$} & $\begin{array}{l}\text { Personal (dissimilarity of } \\
\text { characters, hobbies) }\end{array}$ & & $\times$ & $x$ & $x$ & & & \\
\hline & $\begin{array}{l}\text { Familial (education of } \\
\text { children, relations with } \\
\text { relatives) }\end{array}$ & & $x$ & & & & $x$ & $x$ \\
\hline & Material (financial) & $x$ & & $x$ & $x$ & & & \\
\hline
\end{tabular}




\begin{tabular}{|l|l|c|c|c|c|c|c|c|}
\hline Significance & Conflict causes & $\begin{array}{c}\text { I } \\
\text { couple }\end{array}$ & $\begin{array}{c}\text { II } \\
\text { couple }\end{array}$ & $\begin{array}{c}\text { III } \\
\text { couple }\end{array}$ & $\begin{array}{c}\text { IV } \\
\text { couple }\end{array}$ & $\begin{array}{c}\text { V } \\
\text { couple }\end{array}$ & $\begin{array}{c}\text { VI } \\
\text { couple }\end{array}$ & $\begin{array}{c}\text { VII } \\
\text { couple }\end{array}$ \\
\hline \multirow{3}{*}{ Significant } & Prejudice (lack of flexibility) & & & & & $\times$ & & \\
\cline { 2 - 8 } & Fear (of spouse) & & $\times$ & & & & & \\
\cline { 2 - 9 } & $\begin{array}{l}\text { Domestic (different attitudes } \\
\text { towards domestic-household } \\
\text { matters) }\end{array}$ & & & $\times$ & & & & \\
\hline \multirow{2}{*}{$\begin{array}{l}\text { Less } \\
\text { significant }\end{array}$} & Misunderstandings & & & & & & & \\
\cline { 2 - 9 } & Pettiness & & $\times$ & & & $\times$ & & \\
\cline { 2 - 9 } & Desire to dominate & & & & & & & \\
\hline
\end{tabular}

Before participation in the programme, the causes of marital conflict were determined by very significant reasons, such as: dissimilarity of characters, education of children, relations with relatives, financial difficulties (see Table 2). The following table displays the data of marital conflict causes during and after participation in the "Encounters of Married Couples" programme: (see Table 3).

Table 3. Conflict causes experienced by moderators of the "Encounters of Married Couples" programme during and after participation in it

\begin{tabular}{|c|c|c|c|c|c|c|c|c|}
\hline Significance & Conflict causes & $\begin{array}{c}\text { I } \\
\text { couple }\end{array}$ & $\begin{array}{c}\text { II } \\
\text { couple }\end{array}$ & $\begin{array}{c}\text { III } \\
\text { couple }\end{array}$ & $\begin{array}{c}\text { IV } \\
\text { couple }\end{array}$ & $\begin{array}{c}\mathrm{V} \\
\text { couple }\end{array}$ & $\begin{array}{c}\text { VI } \\
\text { couple }\end{array}$ & $\begin{array}{c}\text { VII } \\
\text { couple }\end{array}$ \\
\hline \multirow{3}{*}{$\begin{array}{l}\text { Very } \\
\text { significant }\end{array}$} & $\begin{array}{l}\text { Personal (dissimilarity of } \\
\text { characters, hobbies) }\end{array}$ & $x$ & $x$ & $x$ & & & $x$ & \\
\hline & $\begin{array}{l}\text { Familial (education of } \\
\text { children, relations with } \\
\text { relatives) }\end{array}$ & & & & $x$ & & & $x$ \\
\hline & Material (financial) & & & & $x$ & & & \\
\hline \multirow{3}{*}{ Significant } & Prejudice (lack of flexibility) & & & $x$ & & $x$ & & \\
\hline & Fear (of spouse) & & & & & & & \\
\hline & $\begin{array}{l}\text { Domestic (different attitudes } \\
\text { towards domestic-household } \\
\text { matters) }\end{array}$ & $x$ & & $x$ & $x$ & & & $x$ \\
\hline \multirow{3}{*}{$\begin{array}{l}\text { Less } \\
\text { significant }\end{array}$} & Misunderstandings & & $x$ & & & $x$ & & \\
\hline & Pettiness & & $x$ & $x$ & & & & \\
\hline & Desire to dominate & & & & & & $x$ & \\
\hline
\end{tabular}

Married couples participated in the "Encounters of Married Couples" programme for many years. Spouses were interviewed about what caused conflicts before and 
after participation in the programme. After participation in the programme the number of conflict causes did not reduce and they remained as important and significant as before participation in the programme. According to the data it is possible to assume that marital conflict causes did not change or the change was insignificant and irrelevant. The root causes of conflicts remained the same and the programme did not erase marital conflict causes.

\subsection{Conflict causes experienced by participants of the "Encounters of Married Couples" programme}

6 married couples with a varied experience of married life took part in the research (see Table 4).

Table 4. Data about the participants of the "Encounters of Married Couples" programme

\begin{tabular}{|l|l|}
\hline Spouses & Duration of marriage \\
\hline I couple & 24 years \\
\hline II couple & 2 years \\
\hline III couple & 30 years \\
\hline IV couple & 4 years \\
\hline V couple & 27 years \\
\hline VI couple & 17 years \\
\hline
\end{tabular}

Every family is a different world; therefore, causes of conflict can be very diverse. G. Navaitis distinguishes two layers of familial difficulties: causes of the current conflict, which may be both significant and non-essential; and context of relationship, which usually determines the evolution of family conflict and its influence on the stability of the family ${ }^{16}$. Spouses' strong belief in marriage, jointly made decisions, husbands' help with housework lead to greater satisfaction in the family and reduce chances of conflicts. Studies by M. Claire, D. Kamp, G. T. Miles revealed that familial conflicts and satisfaction with marriage were inter-related factors ${ }^{17}$.

Research participants indicated these main causes of conflict before taking part in the programme:

16 G. Navaitis, Lietuvosšeima: psichoterapinis aspektas, Vilnius: Tyto Alba 1999.

17 M. Claire, D. Kamp, G. T. Miles, Trajectories of Marital Conflict Across the Life Course: Predictors and Interactions With Marital Happiness Trajectories, "Journal of Family Issues" (2012), Vol. 33 (3), p. 341-368. 
Figure 1. Conflict causes experienced by the participants of the "Encounters of Married Couples" programme before taking part in it

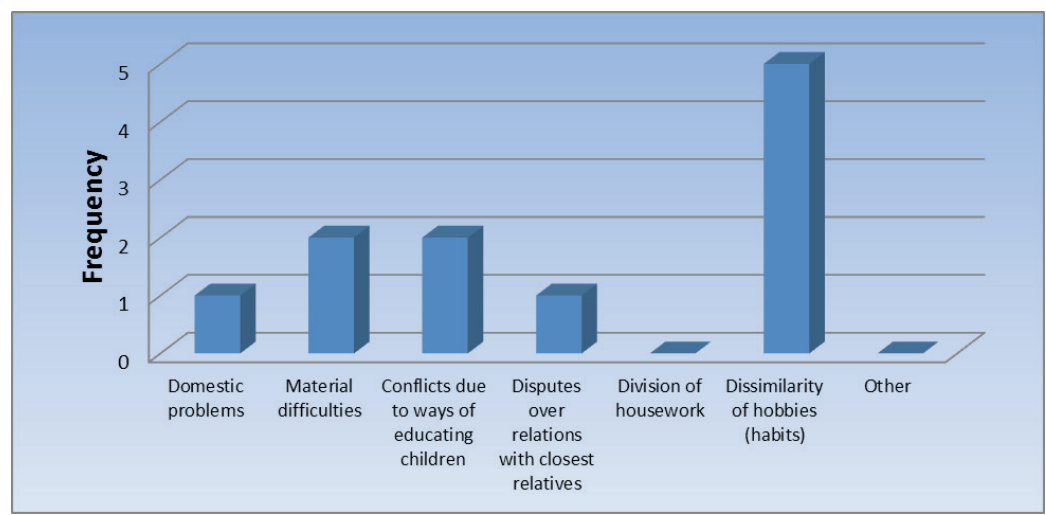

Figure 1 shows that participants of the "Encounters of Married Couples" programme indicated these main conflict causes: domestic problems, material difficulties (lack of money), conflicts due to ways of educating children, dissimilarity of hobbies (habits).

After the "Encounters of Married Couples" programme participants indicated these main conflict causes: (see fig. 2)

Figure 2. Conflict causes experienced by the participants of the "Encounters of Married Couples" programme after taking part in it

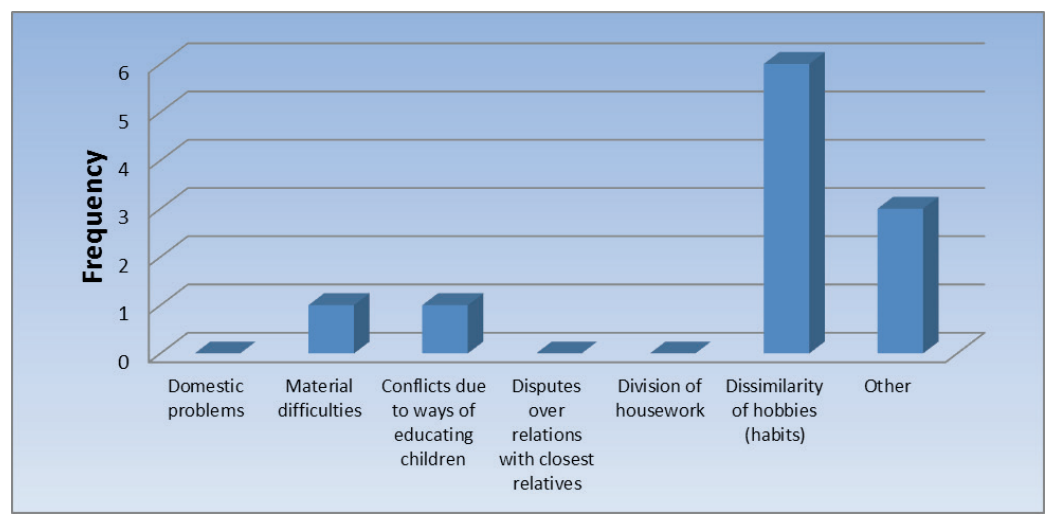

Figure 2 shows that after taking part in the programme the main cause of marital conflict remained the dissimilarity of hobbies (habits). In order to find out the change of marital conflict causes after the programme Wilcoxon criterion was applied, which showed that $\mathrm{p}=0,027<\alpha$. This is statistical significant difference which means that marital conflict causes did change after the programme. Before 
the programme, causes were diverse but after the programme, dissimilarity of hobbies (habits) remained as the significant conflict, while other causes of conflict arose : differences in temperament, spiritual betrayal. After the "Encounters of Married Couples" programme the causes of conflict which were less significant were: domestic problems, material difficulties, conflicts due to ways of educating children and disagreements over relations with closest relatives.

\section{Conclusions}

1. The main marital conflict causes are: dissimilarity of needs, perception, interests and values, material difficulties, immaturity of spouses, inability to communicate in a positive way, not enough time and attention dedicated to communication, distrust and disrespect of partner, inability to distribute roles and responsibilities in marriage, ineptitude to ventilate one's feelings and to hear out the other. The most significant marital conflict causes are: an ineptitude to communicate with each other due to lack of knowledge and poor social and communication skills.

2. a) Conflict causes experienced by the moderators of "Encounters of Married Couples" programme essentially did not change. Marital conflict causes remained as significant as before the programme, they did not change much while participating in the programme. The main marital conflict causes are: financial difficulties, dissimilarity of characters and hobbies, familial problems, conflicts due to ways of educating children and relations with closest relatives, various domestic problems.

b) Spouses, who participated in the "Encounters of Married Couples" programme for the first time, indicated dissimilarity of hobbies (habits) as the main cause of conflict both before and after the programme. Although after the programme, dissimilarity of hobbies (habits) remained significant, the main causes of conflict changed slightly: domestic conflicts and quarrels over relations with relatives declined, but friction due to dissimilarity of hobbies remained. These changes are statistically significant, which means that, after the programme, causes of marital conflict have changed.

\section{Bibliography}

Almonaitienė J., Bendravimo psichologija, Kaunas: Technologija 2001.

Bitinas B., Rupšienè L., Žydžiūnaitė V., Kokybiniu tyrimų metodologija, Klaipėda: S. Jokužio leidykla - spaustuvè 2008. 
Catechism of the Catholic Church, Second edition.

Claire M., Kamp D., Miles G. T., Trajectories of Marital Conflict Across the Life Course: Predictors and Interactions With Marital Happiness Trajectories, "Journal of Family Issues" (2012) Vol. 33 (3), p. 341-368.

Kardelis K., Moksliniu tyrimu metodologija ir metodai, Vadovèlis, Šiauliai: Lucilijus.

Maslauskaitė A., Tarpusavio santykių kokybè Lietuvos šeimose, "Sociologija. Mintis ir veiksmas" (2005) Nr. 1, p. 123-130.

Matulienė G., Šeimos psichologija, Vilnius: Ciklonas 2012, p. 89.

Minnotte K. L. \& Minnotte C. M. \& Pedersen D. E. \& Mannon S. E. \& Kiger G., His and Her Perspectives: Gender Ideology, Work-to-Family Conflict, and Marital Satisfaction, "Sex roles" (2010), Vol. 63, p. 425-438.

Miškinis K., Šeima žmogaus gyvenime, Kaunas: Aušra 2003, p. 392.

Navaitis G., Lietuvos šeima: psichoterapinis aspektas, Vilnius: Tyto Alba 1999.

Orathinkal J., Vansteenwegen A., Couples' conflicts: A territorial perspective, "Sexual and Relationship Therapy" (2006), Vol. 1, p. 28-44.

Sultana A. M., A Study on Stress and Work Family Conflict among Married Women in Their Families, "Advances in Natural and Applied Sciences" (2012), Vol. 6 (8), p. 1319-1324.

Zacchilli T. L., Hendrick C., Hendrick S. S., The Romantic Partner Conflict Scale: A New Scale to Measure Relationship Conflict, "Journal of Social and Personal Relationships" (2009), Vol. 26 (8), p. 1073-1096. 